УДК 636.638.1.09:595.42

(C) 2018

Свстаф'єва В. О., доктор ветеринарних наук, професор, Назаренко О. С., аспірант

(науковий керівник - доктор ветеринарних наук, професор В. О. Свстаф'єва)

Полтавська державна аграрна академія

\title{
БІОЛОГІЧНІ ОСОБЛИВОСТІ СЕЗОННОЇ ДИНАМІКИ VARROA DESTRUCTOR (ANDERSON AND TRUEMAN, 2000) В УМОВАХ ПОЛТАВСЬКОЇ ОБЛАСТІ
}

\section{Рецензент - доктор ветеринарних наук, професор А. А. Замазій}

Наведено дані щодо визначення показників зараженості медоносних бджіл Varroa destructor y кліматичних умовах Полтавської області залежно від сезону з урахуванням біологічних особливостей паразитичних кліщів. Установлено, щзо сезонна динаміка вароозу характеризується зростанням показників екстенсивності інвазії та індексу рясності у літньоосінній період року, а показників інтенсивності інвазї - взимку та влітку. Доведено, щзо впродовж року кількість кліщів на одній робочій бджолі коливається в межах від 1 до 8 екз. Біологічні особливості клімів характеризуються активізацією паразитування на бджолах влітку (до 8 екз. імаго) та восени (до 7 екз.).

Ключові слова: варооз, медоносні бджоли, сезонна динаміка, екстенсивність, інтенсивність інвазї, індекс рясності.

Постановка проблеми. В процесі еволюції медоносні бджоли як суспільні комахи гарно пристосувались до умов існування і займають на Землі великий ареал. Однією з форм пристосування стала генетично обумовлена необхідність існувати єдиним складним великим організмом сім'єю. Жодна з іiі структурних одиниць (матка, робочі бджоли та трутні) не може існувати окремо. Така форма існування забезпечила процвітання бджіл як виду. Сім'я, що складається 3 декількох десятків особин при одній матці, має можливість пережити найнесприятливіші умови навколишнього середовища й успішно розмножуватися $[1,6]$.

Бджільництво України знаходиться у двох секторах - суспільному, де є великі за розміром пасіки, в яких нараховується близько мільйона бджолиних сімей, та в індивідуальному користуванні пасічників-любителів міст і сіл. Індивідуальні пасіки, як правило, невеликі, але загальна кількість бджолиних сімей у них становить понад 5 млн [10, 11].

На заваді розвитку галузі стоять заразні та незаразні хвороби бджіл та їх розплоду, які завдають значних збитків бджільництву. До таких хвороб належить i варооз, який є глобальною проблемою для бджільництва, тому що інвазія призводить до ослаблення і зменшення чисельності бджолосімей, негативного впливу на навколишне середовище, зниження врожайності ентомофільних сільськогосподарських культур і загальної продуктивності галузі в цілому $[3,4,9]$.

Аналіз останніх досліджень і публікацій, у яких започатковано розв'язання проблеми. Науковці зазначають, що впродовж останніх років паразит Varroa destructor $€$ одним із найбільш небезпечних шкідників медоносних бджіл (Apis mellifera). Поширення вароозу прийняло характер панзоотій і охопило всі райони світу, де можливе проживання медоносних бджіл $[12,13$, 14].

Так, згідно з даними І. Г. Маслій та ін. (2015), захворюваність бджіл на варооз на території 17 областей України збільшується із року в рік. Так, у 2006 році цей показник був на рівні 9,7\%, у 2007 p. - 14,0\%, 2008 p. - 15,8\%, 2009 p. $18,6 \%, 2010$ р. - 41,9\%. Екстенсивність інвазії реєстрували у межах (2-100)\% - на дорослих бджолах та (2-70) \% - у розплоді. Одночасно встановлені авторами відмінності залежали від багатьох факторів, зокрема біотичних, а також абіотичних [8].

На території Житомирської області, згідно 3 офіційними даними, найбільш розповсюдженою паразитарною хворобою за останні 8 років $\epsilon$ варооз, що становить 58 \% від усіх паразитарних хвороб [2].

Численні дослідження, проведені науковцями 3 метою визначення зараженості сімей медоносних бджіл вароозними кліщами в районах Приморського краю, що розташовані в різних природно-кліматичних зонах упродовж 19942014 рр., показали наявність у розплоді робочих бджіл, трутнів і самих бджіл лише одного виду Varroa destructor [5]. Інші автори зазначають, що на території Дальнореченського району на Дальньому Сході Росії варооз є одним з найнебезпечніших захворювань бджіл [7].

Отже, у зв'язку зі значним розповсюдженням вароозу бджіл, високою пристосованістю пара- 


\section{ВЕТЕРИНАРНА МЕДИЦИНА}

зитичних кліщів до різних кліматичних умов, а також зниженням рентабельності пасік внаслідок даної інвазії, актуальним є визначення біологічних властивостей збудника вароозу залежно від сезонних коливань в умовах різних регіонів України.

Тому, метою роботи було вивчення біологічних особливостей сезонної динаміки збудника вароозу медоносних бджіл у кліматичних умовах Полтавської області.

У завдання досліджень входило встановити екстенсивність та інтенсивність вароозної інвазії у різні пори року; дослідити зміни показників інтенсивності інвазії та індексу рясності залежно від сезонних коливань.

Матеріали і методи досліджень. Дослідження проводилися упродовж 2017 року на базі наукової лабораторії кафедри паразитології та ветеринарно-санітарної експертизи Полтавської державної аграрної академії та в умовах приватних пасік Полтавської області.

Показники сезонних коливань зараження збудником вароозу визначали кожного місяця за результатами клінічних та лабораторних досліджень робочих бджіл згідно з загальноприйнятими методиками. Під час діагностики визначали вид кліща, а у випадку паразитологічного об- стеження бджолосімей та робочих бджіл - екстенсивність, інтенсивність інвазії та індекс рясності (EI, II та IP).

Статистичну обробку результатів експериментальних досліджень проводили шляхом визначення середнього арифметичного (M), його похибки (m), а також встановлювали показники мінімальних та максимальних значень (min, max).

Результати досліджень. За результатами проведених паразитологічних досліджень встановлено, що варооз є поширеною акарозною інвазією медоносних бджіл на території Полтавської області, який викликається кліщем виду Varroa destructor (Anderson and Trueman, 2000). Уражених бджіл виявляли впродовж року, однак були визначені певні закономірності у показниках залежно від пори року (рис. 1, 2). Так, максимальну кількість інвазованих робочих бджіл виявляли у літньо-осінній період року (EI 18,17-15,17\%). Найменші значення ураженості бджіл встановлювали взимку (6,83 \%), а навесні, внаслідок активізації кліщів, їх розмноження, EI починала зростати i становила 10,00\% (рис. 1).

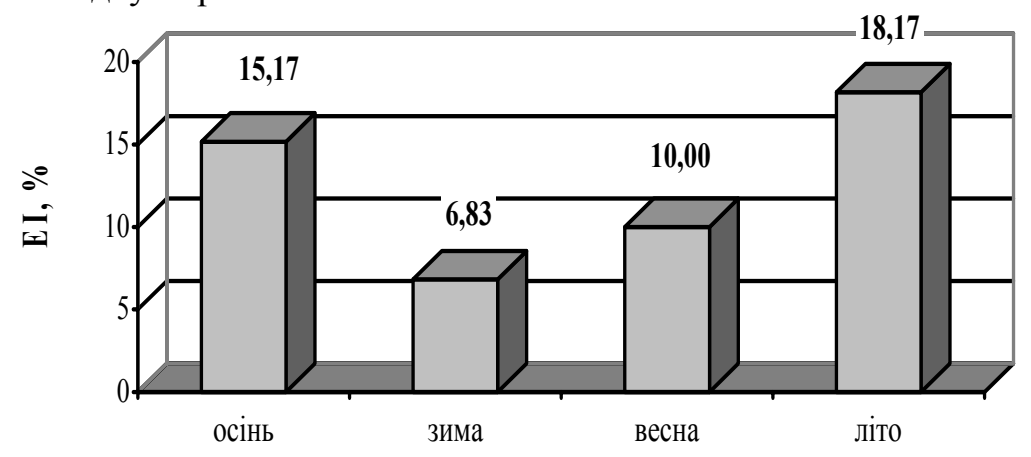

Рис. 1. Показники екстенсивності вароозної інвазї̈ медоносних бджсл залежно від пори року

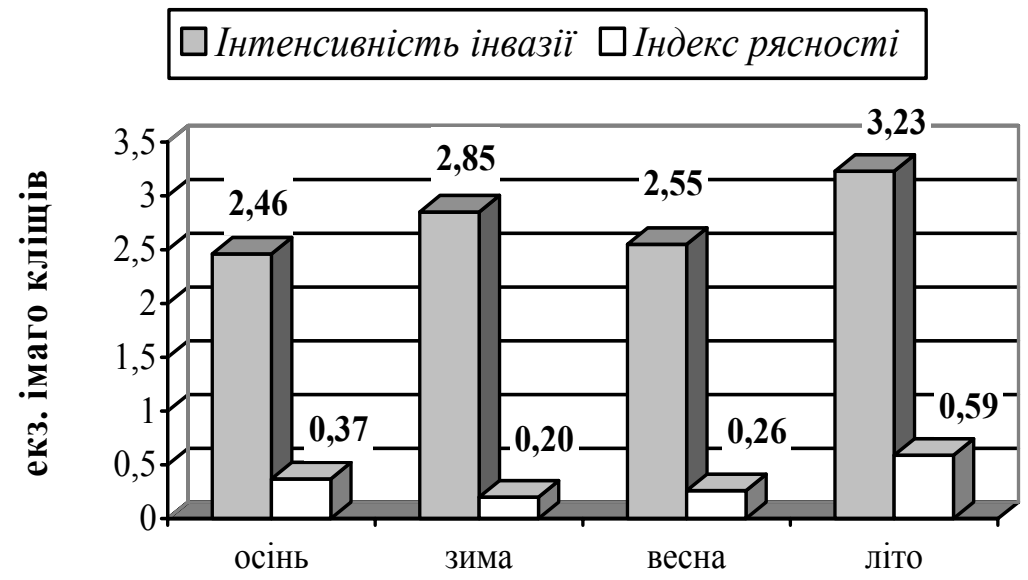

Рис. 2. Показники інвазованості робочих бджіл Vаrroa destructor залежно від пори року 


\section{$\square 1$ екз. $\square 2$ екз. $\square 3$ екз. $\mathbf{\$} 4$ екз. $\square 5$ екз. 图 6 екз. $\square 7$ екз.}

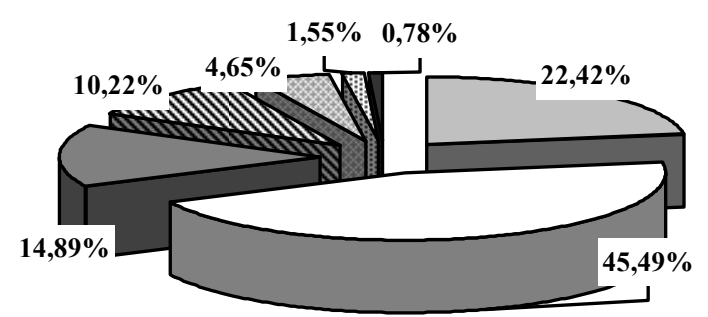

осінь
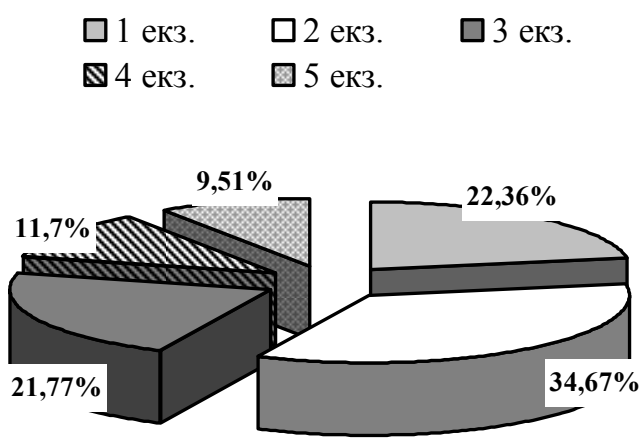

весна
$\square 1$ екз.
$\square 2$ екз.
3 екз.
\$ 4 екз. $\square 5$ екз.

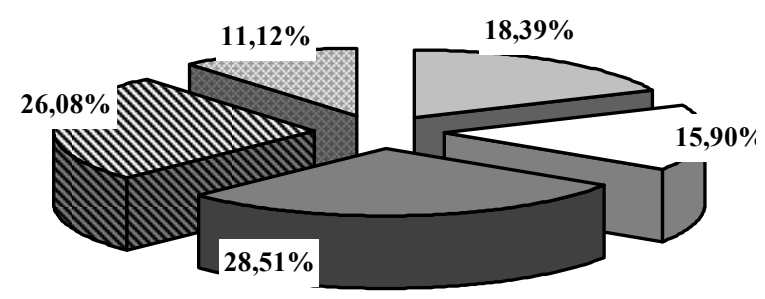

зима
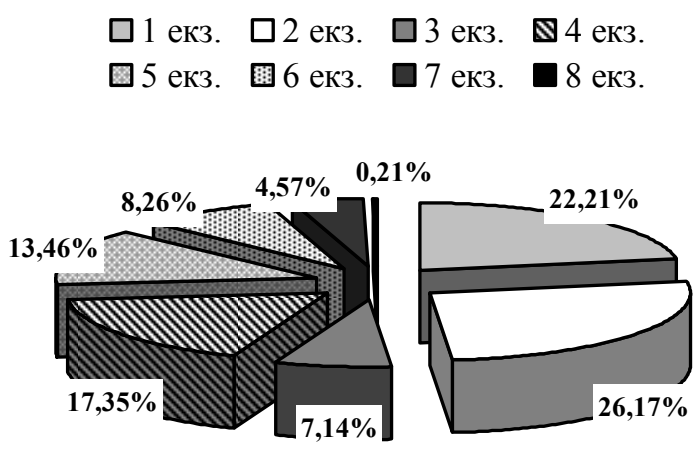

літо

\section{Рис. 3. Відсоткове співвідночення кількості Varroa destructor на бджолі залежно від пори року}

Разом із тим, максимальну кількість кліщів на робочих бджолах виявляли у зимовий (II $2,85 \pm 0,21$ екз.) та літній період року $(3,23 \pm 0,18$ екз.). Показники індексу рясності за вароозу характеризувалися ідентичними коливаннями впродовж року відповідно до показників екстенсивності інвазії. Так, влітку IP був найвищім і становив 0,59 екз., а в подальшому, впродовж осені він знижувався до 0,37 екз. і сягав мінімальних значень узимку (до 0,20 екз.). Впродовж весняного періоду IP зростав до 0,26 екз. (рис. 2).

Одночасно доведено, що біологічні особливості $V$. destructor характеризуються різними показниками їх кількості на одній робочій бджолі залежно від пори року (рис. 3). Так, упродовж року на одній бджолі виявляли від 1 до 8 імаго $V$. destructor. Його біологічні особливості паразитування на бджолах змінювалися відповідно до кліматичних умов сезонних коливань.

Найбільшу кількість кліщів, що паразитували на одній бджолі зареєстровано впродовж літньоосіннього періоду (від 7 до 8 екз.), найменшу - у зимово-весняний період року (до 5 екз.). Причому 1 екз. імаго кліща виявляли у 22,21-22,42\% випадків впродовж весняного, літнього та осіннього періодів, а у $18,39 \%$ - впродовж зимового періоду. Найбільше виявляли по 2 екз. на одній робочій бджолі.

Впродовж року відсоток інвазування коливався: восени - 45,49\%, навесні - 34,67\%, влітку $26,17 \%$, взимку $-15,90 \%$. Найбільший відсоток інвазування бджіл - 3 екз. кліщів встановлювали у зимово-весняний період (28,51-21,77\%), найменший - восени (14,89 \%) та влітку $(7,14 \%)$.

Кліщів Varroa у кількості 4 екз. встановлено взимку в $26,08 \%$ випадків, влітку - 17,35 \%, навесні $-11,70 \%$, восени - 10,22\%. Паразитування 5 екз. кліщів частіше виявлено впродовж літа (до 13,46\%), менший відсоток інвазування бджіл зареєстровано взимку $(11,12 \%)$, навесні $(9,51 \%)$ та восени $(4,65 \%)$. Шість та сім кліщів відловлювали на бджолі тільки у літньо-осінній період року (1,55-8,26 \% та $0,78-4,57 \%$ відповідно).

Найбільш сприятливим періодом для розмноження та нападу на бджіл виявився літній, найбільш теплий період року (до $0,83 \%$ ), впродовж якого виявляли кліщів на одній робочій бджолі у кількості 8 екз.

Отже, варооз бджіл характеризується певною сезонною динамікою у кліматичних умовах Полтавської області, а також залежністю біологічних властивостей від пори року. 


\section{ВЕТЕРИНАРНА МЕДИЦИНА}

\section{Висновки:}

1. Варооз є поширеною інвазією медоносних бджіл на території Полтавської області. Екстенсивність інвазії впродовж року становить 6,83-

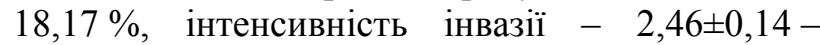
$3,23 \pm 0,18$ екз., індекс рясності - 0,20-0,59 екз.

2. Встановлено залежність ураження робочих бджіл Varroa destructor від пори року. Пік вароозної інвазії відзначено влітку, восени та взимку.

3. За результатами паразитологічних дослі-

\section{БІБЛІОГРАФІЯ}

1. Бабич I. A. Бджільництво / I. А. Бабич, О. Г. Мегедь. - К. : Урожай, 1979. - 247 с.

2. Галатюк O. С. Епізоотологічний моніторинг заразних хвороб медоносних бджіл у північно-західному регіоні України / О. Є. Галатюк, С. Ф. Тушак // Науковий вісник Національного університету біоресурсів і природокористування України. - К., 2016. - Вип. 237. - С. 372-379.

3. Сфіменко T. М. Варооз бджіл та заходи зниження його шкодочинності / Т. М. Єфіменко // Пасіка. - 2013. - №4. - С. 14-16.

4. Квасников A. K. Варроатоз медоносных пчел / А. К. Квасников. - К., 1990. - 72 с.

5. Кузнецов В. Н. О паразитировании клещей рода Varroa oudemans, 1904 (Acari: Varroidea) на китайской восковой пчеле Apis cerana cerana Fabricius, 1793 (Hymenoptera: Apidae) в Приморском крае / В. Н. Кузнецов, А. С. Лелей // Чтения памяти А. И. Куренцова. - Владивосток : Дальнаука, 2005. - Вып. 16. - С. 39-46.

6. Лаврехин Ф. А. Биология медоносной пчелы / Ф. А. Лаврехин, С. В. Панкова. - М. : Колос, 1983. - 304 c.

7. Маркова T. О. Заболевания пчел в Дальнереченском районе (Приморский край, Дальний Восток России) / Т. О. Маркова, Н. В. Репш, М. В. Маслов, С. Е. Егоренчев // Вестник Орен- джень робочих бджіл максимальну кількість кліщів $V$. destructor виявляли влітку (до 8 екз. імаго) та восени (до 7 екз.), мінімальну - взимку та навесні (до 5 екз.).

Перспективи подальшої роботи в изьому напрямі. Перспективами подальших досліджень $є$ визначення впливу пори року на морфологічні та метричні показники імагінальних форм Varroa destructor.

бургского государственного университета. 2016. - №4 (192). - С. 79-81.

8. Маслій І. Г. Моніторинг хвороб бджіл в Україні / І. Г. Маслій, С. М. Нємкова, Л. П. Ступак, О. В. Десятникова // Ветеринарна медицина : міжвід. темат. наук. зб. - Х., 2015. - Вип. 101. C. 116-121.

9. Мусієнко О. В. Паразитоценоз бджолиної сім’і / О. В. Мусієнко, В. М. Мусієнко, О. С. Кистерна // Вісник Сумського національного аграрного університету. - 2010. - Вип. 3 (26), 2010. - С. 103-108.

10. Полішук В. П. Пасіка / В. П. Поліщук, В. А. Гайдар. - К., 1993. - 272 с.

11. Поліщук В. П. Бджільництво : підручник / В. П. Поліщук. - К. : Вища школа, 2001. - 287 с.

12. Пчелиный клещ Varroa jacobsoni / [Акимов И. А., Гробов О. Ф., Пилецкая И. Ф. и др.]. К. : Наукова думка, 1993. - 254 с.

13. Gulati R. Varroa, enemy of honeybees: its effect, life cycle and control / R. Gulati, S. K. Sharma, R. K. Saini // Technology Bull. 2009. - 24 p.

14. Kokkinis $M$. Population dynamics of Varroa destructor in colonies of Apis mellifera macedonica in Greece / M. Kokkinis, V. Liakos // Apidologie. 2004. - №43 (4). - P. 150-154. 